\title{
Human livelihoods and protected areas in Gabon: a cross-sectional comparison of welfare and consumption patterns
}

\author{
Steffen Foerster, David S. Wilkie, Gilda A. Morelli, Josefien Demmer \\ Malcolm Starkey, Paul Telfer and Matthen Steil
}

\begin{abstract}
Understanding the role that protected areas play in the livelihood security of local communities is essential to ensure that local people are not left shouldering the costs of what is a public good, and to help maintain robust local and national constituencies for biodiversity conservation. To provide baseline data for a longitudinal study on the effects of newly established national parks on human livelihoods in Gabon we conducted a cross-sectional study that compared livelihood indicators between communities that do, and do not, use natural resources within protected areas. We interviewed 2,035 households in 117 villages at four sites, recording income, consumption, education, health indicators and social capital, and village characteristics such as distance to markets, distance to park boundaries, and land cover within a 5-km radius. Our results indicated that closed rainforest coverage was greater around park than control villages and that this difference was associated with a greater reliance of park households on forest resources. However, we found no systematic differences in most livelihood measures between park and control households. Instead, the relationship between household livelihood measures and proximity to parks varied in idiosyncratic ways between sites, suggesting that determinants of human welfare are highly localized and cannot be generalized to larger spatial scales.
\end{abstract}

Keywords Consumption, Gabon, household surveys, human livelihoods, poverty, protected areas, tropical forests

\section{Introduction}

$\mathrm{N}$ atural resource conservation is needed when a locally or globally valued natural resource is being depleted

StefFen Foerster (Corresponding author), DAvid S. WilkiE* and GildA A. Morelli Boston College, Office of the Provost and Dean of Faculties, Waul House, 270 Hammond Street, Chestnut Hill, Massachusetts 02467, USA. E-mailsf2041@columbia.edu

Josefien Demmer Institute for Biodiversity and Ecosystem Dynamics, University of Amsterdam, Amsterdam, The Netherlands

Malcolm Starkey Wildlife Conservation Society, Libreville, Gabon

Paul Telfer Wildlife Conservation Society, Brazzaville, Republic of Congo

MatThew STEIL World Resources Institute, Washington, DC, USA

*Also at: Wildlife Conservation Society, Waltham, Massachusetts, USA

Received 7 July 2010. Revision requested 25 October 2010.

Accepted 9 December 2010. and risks being lost through unsustainable use. Protected areas are one of the most important conservation tools available for lowering resource use to sustainable levels by either restricting who has access to the resource, or metering how much of the resource legitimate users can extract, or both (Rowcliffe et al., 2004; Ling \& Milner-Gulland, 2006).

Not surprisingly, restricting the use of natural resources in protected areas can have a multitude of social and economic impacts on local people who have traditionally relied on these resources for their livelihoods (Ferraro, 2002; Cernea \& Schmidt-Soltau, 2006; West et al., 2006; McElwee, 2010), often exacerbating poverty and increasing conflict between humans and wildlife (Ghimire \& Pimbert, 1997; West et al., 2006). However, protected areas are also known to generate direct and indirect benefits to local communities, not only as a source of food but also by providing income and a sense of spiritual well-being (Scherl et al., 2004; Dudley et al., 2008; Taylor, 2009; Stolton \& Dudley, 2010). Combining conservation practice with poverty alleviation has helped to improve acceptance of conservation strategies in local communities and assure the long-term viability of protected areas (Wells \& McShane, 2004; Naughton-Treves et al., 2005). However, the contradictory nature of the effects protected areas may have on local people appears to weaken political support for establishing and managing protected areas, which jeopardizes the continued use of this important biodiversity conservation tool (Sanderson \& Redford, 2003). The controversy over the relationship between protected areas and human welfare (Brockington et al., 2006; Roe, 2008) calls for increasing efforts to test this relationship empirically by comparing poverty indicators and developmental trajectories between communities that rely on protected area resources and those that do not (Wilkie et al., 2006).

Most case studies of the impact of parks on people have been limited to one-off assessments of communities living within or in close proximity to protected areas (Hegde \& Enters, 2000; Ferraro, 2002; Crookes et al., 2007; Nyahongo et al., 2009; McElwee, 2010; Mullan et al., 2010). Such studies are not well suited to establish a causal connection between poverty and protected area management, however, because they cannot distinguish between pre-existing conditions and changes introduced solely by the existence of protected areas. A correlation between poverty and the presence of protected areas can exist simply because such 
areas are often established in the poorest, most remote parts of a country where large tracts of land remain undisturbed and where people are the last to attain access to markets and social services. A recent global analysis found that protected areas in poor countries are orders of magnitude larger and have more access and use restrictions than those in wealthier nations, yet no relationship was found between national indicators of poverty and the extent of protected areas (Upton et al., 2008). Similarly, a global cross-sectional assessment of infant mortality, a reliable poverty indicator, found no evidence for elevated levels of poverty among communities that live close to parks, even where resource use was most restricted (de Sherbinin, 2008).

To evaluate the cause and effect relationship between protected areas and people's livelihoods adequately, rigorous long-term longitudinal studies are needed that compare human welfare measures before and after the establishment of protected areas (Wilkie et al., 2006) in households that traditionally use park resources and a matching set of control households that have no prior history of resource use within the park. The People and Parks project currently underway in Gabon is one of the first to conduct a rigorous before-after control-impact (BACI) assessment of the role protected areas play in changing people's livelihoods. The dataset presented here is the result of a baseline survey conducted before the implementation of resource management practices in Gabon's recently established National Parks, with the purpose of comparing livelihood indicators between communities that traditionally rely on park resources and those that do not. If the use of park resources (e.g. bushmeat) has a significant influence on livelihood measures (Blaney et al., 2009) any future management strategy that prohibits the use of these resources would risk a decline in human welfare and require simultaneous efforts to ensure that local people do not unfairly shoulder the cost of conserving biodiversity.

\section{Methods}

\section{Study sites}

Of the 12 new terrestrial National Parks established in 2002 by President Bongo Odimba we chose parks that fulfilled the following conditions: (1) no prior legal protection status, anti-poaching or community development project, (2) reasonable likelihood of receiving intensive management in the next few years, (3) not bordering a neighbouring country, and (4) with existing communities that regularly use park resources. The final selection was Biringou, Waka, Ivindo and Monts de Cristal National Parks (Fig. 1).

\section{Human population}

Starting in the early colonial period at the turn of the 20 th century and continuing through to independence in 1960 rural families were forcibly moved by the state to live along the few roads that connect Gabon's towns to the capital city Libreville. Today most rural Gabonese either live in small market towns of 5,000 inhabitants or less, or in villages, often of related individuals, of 3-50 families. These village households generally employ a mixed livelihood strategy that includes farming of stable crops such as manioc, plantains, maize and yams, subsistence hunting in fields and in the forest surrounding the village, and small enterprises (sale of bushmeat, agricultural crops, palm wine, sleeping mats, brooms and other items). Labour allocation varies with the agricultural calendar and can include wage labour in logging and mining concessions.

\section{Village selection}

After initial testing and refining of survey methods in 20052006 we proceeded in three stages. Firstly, we conducted a participatory assessment of resource use to determine whether or not village residents presently or historically used or had claims over natural resources now within the boundary of the National Park. Villages with prior or present use or claims were designated park villages $(n=72$, distance from park boundary $2-37 \mathrm{~km}$, median $=16 \mathrm{~km}$ ), those without were designated non-park, i.e. control villages $(n=45$, distance from park boundary $20-128 \mathrm{~km}$, median $=60 \mathrm{~km})$. We attempted to match as closely as possible the number of park and control villages (Table 1) but this was not always possible given a low population density and the spatial distribution of villages in relation to park boundaries.

Secondly, we conducted an extensive survey of all park and control households to capture information on household composition, education, health, income and wealth (assessed with a standard basket of goods; see below). Thirdly, we conducted an intensive survey of a subset of park and control households at three sites ( $\mathrm{n}=56$ villages; Table 1, Fig. 1) to capture information on consumption of wild, cultivated and manufactured goods. To account for seasonal changes in consumption patterns we conducted two separate intensive surveys: February-May 2006 (dry season) and September-December 2006 (wet season). Two researchers spent 1 week in each village and conducted household interviews on days 1,3 and 5 for $50 \%$ of households, and on days 2, 4, and 6 for the remaining $50 \%$. On each visit the interviewers asked the adult male and female heads of household to recall all goods consumed (i.e. brought over the threshold of the house) during the previous 48 hours. Prior surveys on bushmeat consumption demonstrated that subjects are rarely willing to divulge where they hunt or set traps, probably because of fear of prosecution. Therefore, we chose simply to ask whether the goods consumed came from forests, agricultural fields or fallows, or from shops and markets. 


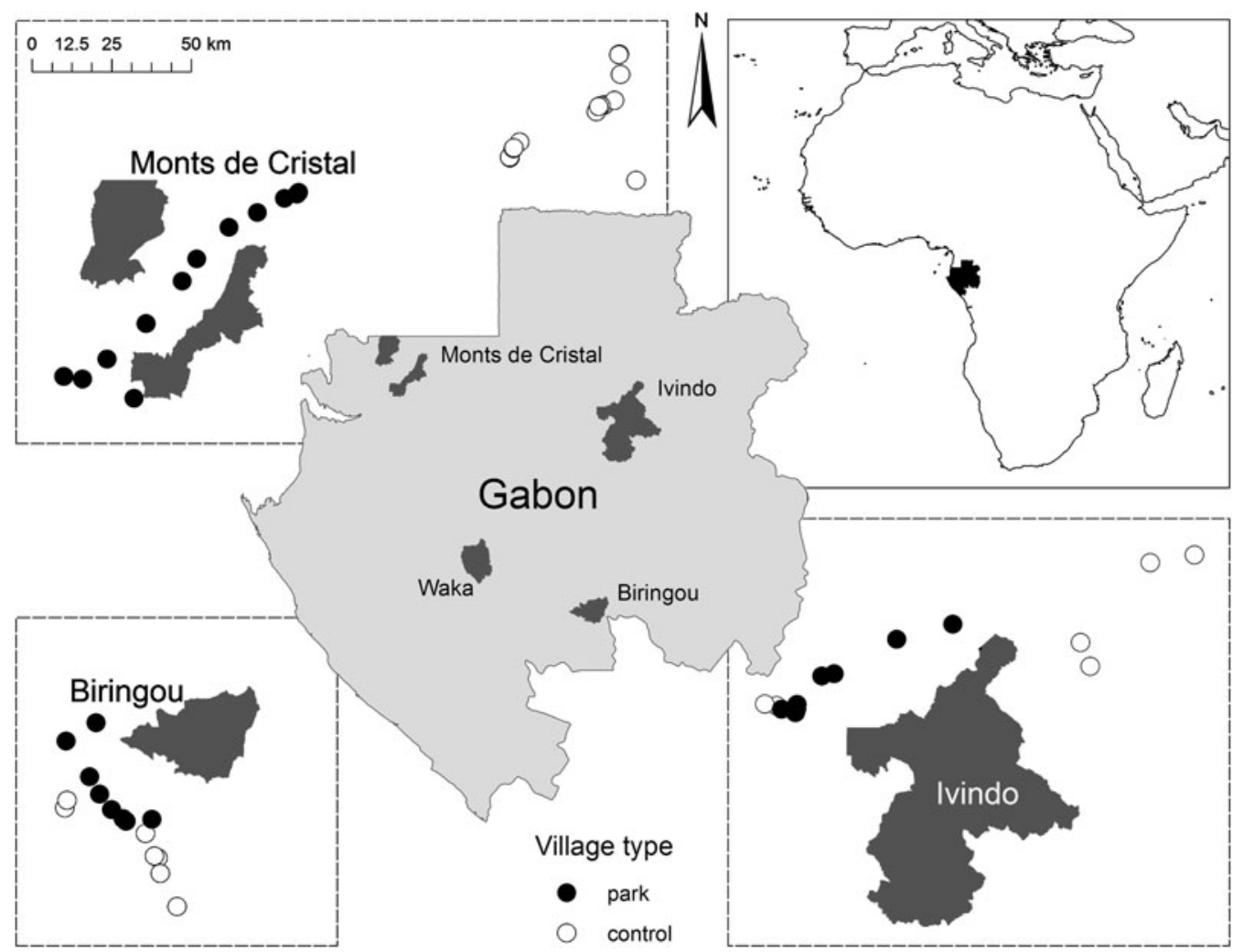

FIG. 1 The locations of the four National Parks in Gabon where the study took place (centre), and the areas and village locations in relation to three of the four National Parks (only the villages included in the intensive survey are included; see text for details). The top right figure shows the location of Gabon in West Africa.

\section{Village level information}

For each village we recorded name, geographical location, number of households, market access, travel time to social services, access to electricity and whether village members participate in community work. We analysed land cover in a $5-\mathrm{km}$ radius around each village using GlobCover v. 2.2 (ESA, 2008). GlobCover provides gridded global land cover at a resolution of $300 \mathrm{~m}$ (MERIS Full Resolution Level $1 \mathrm{~B}$

TABLE 1 Number of villages/households at the four National Park study sites (Fig. 1) included in the extensive and intensive surveys (see text for details). Not all households provided information on each of the indicators, leading to variable sample sizes.

\begin{tabular}{lcrlr}
\hline & Biringou & Ivindo & $\begin{array}{l}\text { Monts de } \\
\text { Cristal }\end{array}$ & Waka* $^{*}$ \\
\hline Extensive & & & & \\
Control & $9 / 167$ & $8 / 274$ & $20 / 276$ & $8 / 203$ \\
Park & $15 / 304$ & $14 / 300$ & $24 / 293$ & $19 / 218$ \\
Intensive & & & & \\
Control & $6 / 69$ & $6 / 182$ & $14 / 201$ & \\
Park & $8 / 100$ & $9 / 187$ & $13 / 185$ & \\
\hline
\end{tabular}

*Study villages at Waka National Park could not be included in the intensive survey because roads to this part of the country became impassable at that time product), and covers December 2004-June 2006. Land cover classes are regionally-tuned and defined according to the UN Land Cover Classification System (FAO, 2005). All spatial analyses were carried out with ArcGIS v. 9.3.1 (ESRI, Redlands, USA).

\section{Demography and well-being}

We gathered demographic information (age, gender, years of education and ethnicity) for all household residents. Residents were defined as all individuals sleeping in the residence during the 7 days prior to the survey. We gathered anthropometric information (body-mass index (BMI; weight/(height) $)^{2}$ ), percentage body fat and mid upper-arm circumference) for all household residents $>_{1}$ year of age as a proxy for short-term health. All residents were asked how often they had suffered from fever, diarrhoea and the common cold in the previous month. In addition, the head of each household was asked to provide a self-assessment of their nutritional well-being as the number of days in the previous month they had not eaten anything. Community trust was assessed by asking participants whether they would trust a neighbour to look after their house when they had to leave the village, to look after their money, or whether a machete left outside overnight would still be there in the morning. 
We followed the guidelines for protection of human subjects as outlined by the Belmont Report (The National Commission for the Protection of Human Subjects of Biomedical and Behavioral Research, 1979) and data collection protocols were reviewed and authorized by the Boston College Institutional Review Board. All researchers were required to complete an online Human Subjects Protection certification course and participated in a 2-week training programme on collecting anthropometric measurements. Potential subjects were given details, in their natal language, about the study and informed that it was a university research project to determine how national parks affect the lives of people in Gabon who live near them. We informed potential subjects that if they participated they would remain anonymous and their identity would never be revealed at any time during the study or in any reports or publications arising from the study. Potential subjects were also informed that they had the right to refuse to answer any question or to end their participation in the study at any time. Prior to each data collection event subjects were reminded of the purpose of the study and again asked if they still wished to participate. We asked parents' permission to collect anthropometric measurements of their children under the age of five. Information about children's health measures was provided to parents only. No remuneration was offered to participants.

\section{Income}

Household wealth was assessed from the total value of a standard basket of 22 assets owned by any household member. We chose the basket of assets to include items that span a broad range of values and thus were likely to be owned by households that differ widely in wealth: cooking equipment, firearms, beds, mattresses, lamps, watches, clocks, refrigerators, freezers, music players, televisions, mobile phones, electric fans, air conditioners and vehicles. All values were recorded in XAF and reported in purchasing power parity USD (PPP\$). We used the PPP conversion factor for private consumption in 2005, which was 443.7 (World Bank, 2008). We used the current village price for each asset and did not impute a depreciated value based on the age of each owned asset, as this has been shown (Demmer \& Overman, 2001) not to significantly influence wealth assessment and considerably reduces the time to gather asset data, thus minimizing subject fatigue and data error.

To estimate transitory income all household residents were asked to recall the amount of income generated during the previous month from salaries, wages, bonuses, pensions, remittances, and revenue from commercial enterprises and the sale of forest goods. Value of annual crops was assessed by asking subjects to recall the total sales price of each crop that is only harvested and sold once per year (e.g. coffee, cacao, peanuts). We divided income into categories that reflected income ranges and let each subject privately point to the category their respective incomes would fall into.

\section{Measuring consumption}

Heads of households were asked to recall all produce, natural resources and manufactured goods consumed (purchased, hunted, caught or otherwise obtained) during the 48 hours prior to the survey by all members of the household. For each consumed item, heads of households provided an actual or estimated value in XAF as well as the number of units consumed. For items produced by the household (e.g. bushmeat trapped or hunted) we estimated its value by asking interviewees the price they would have sold it for, or the quantity of a good with a known price (e.g. $1 \mathrm{~kg}$ of sugar) they would trade if for.

To obtain an adequate measure of animal protein consumption that was not influenced by variation in market value we transformed all protein consumption (except tinned fish) into $\mathrm{kg}$. As the majority of protein consumption was based on units other than $\mathrm{kg}$, we estimated the weight for each item in one of four ways: (1) For some frequently used units we obtained mean weights from a previous consumption study among urban and rural villages in Gabon (Wilkie et al., 2005); (2) When the weight per unit was not known we used the price of whole specimens to estimate weight consumed as (value consumed) * (mean weight whole) / (mean price whole); (3) When price data for whole animals were not available for the village in which they were consumed ( $15 \%$ of all cases) we used the mean price for the whole animal calculated across all villages; (4) If a mean weight of the whole animal could not be obtained from our records we used mean weights in the literature for an adult of that species, if available. For 62 records weight could not be calculated by these methods and we excluded those records from analyses. We excluded an additional 60 records because the respective households were only surveyed on 1 or 2 days. The final dataset included 3,633 consumption records.

\section{Statistical analyses}

Consumption and income measures were expressed per adult male equivalent (AME) to control for different demographic compositions of households (Deaton, 1997). Conversion into AME was based on estimated daily food energy requirements $\left(\mathrm{kcal} \mathrm{day}^{-1}\right)$ for different ages and genders (James \& Schofield, 1990). Most livelihood measures were greatly skewed and many zeros prevented transformation to normality. We therefore used Mann-Whitney $U$ tests to evaluate differences between park and control households. If parks themselves had an effect on livelihoods we would expect some of our indicators to correlate with distance to the nearest park boundary, rather than the 
designation of park vs control that ignores intra-group variation in spatial separation from the parks. To test this hypothesis we constructed generalized linear models with distance to nearest park boundary as a covariate. To account for between-site variation in dependent variables we also entered study site and its interaction with distance as fixed effects. We modelled dependent variables using a log-link function. To account for correlation between independent factors and assess the relative importance of different measures to distinguish between park and control households we used binary logistic regression with park/ control as the dependent variable, and the following predictor variables entered through a forward likelihood ratio selection criterion: distance to park, income, wealth, education, household size (AME), total consumption (XAF), consumption of protein except canned meat and fish $(\mathrm{kg})$, consumption of game meat, chicken, livestock and fish $(\mathrm{kg})$, consumption of vegetables (XAF), consumption of non-food (XAF), mean BMI, and distance to market (km). Significance levels for all statistical tests were set to $\alpha=$ 0.05. All tests were two-tailed and performed with PASW Statistics v. 17 (SPSS Inc., Chicago, USA).

\section{Results}

\section{Community indicators}

Park villages were significantly smaller than control villages (mean $109 \pm$ SE 10 vs $155 \pm$ SE 16 inhabitants, respectively; $Z=-2.5, \mathrm{P}=0.011, \mathrm{n}=45$ vs 72 control and park villages). Distance to markets and larger towns (in hours) was not different between control and park villages (Table 2; markets: $Z=1.2, \mathrm{P}=0.22$; larger towns: $Z=1.3, \mathrm{P}=0.21$; see Table for sample sizes). Control villages were significantly further away from park boundaries than park villages (median $=60$ vs $16 \mathrm{~km}$ for control and park villages, respectively; $Z=-8.7, \mathrm{P}<0.001$ ) but distance was more variable among control than park villages (Table 2 ). Control villages were further from the nearest dispensary than park villages (median $=1.0$ vs $0.5 \mathrm{~h} ; Z=-2, \mathrm{P}=0.04$ ) but did not differ in travel time to the nearest pharmacy (median $=1.5$ vs $1.0 \mathrm{~h} ; Z=0.1, \mathrm{P}=0.94$ ) or hospital (median $=1.5$ vs $1.25 \mathrm{~h} ; Z=0, \mathrm{P}=1.00$ ).

The median level of trust was 2 in control households (i.e. they answered yes to two of the three trust-related questions) and 1 in park households $(Z=-3.1, \mathrm{P}=0.002$, $\mathrm{n}=922$ vs 1,137 control and park households, respectively). However, the only difference between park and control households appeared in response to the question about trusting a neighbour with money; members of control households were more likely to show trust than park households $(Z=-5.4, \mathrm{P}<0.001, \mathrm{n}=1,338$ vs 1,774 participants in control and park households, respectively).
TABLE 2 Selected village and livelihood measures (mean \pm SE (n)) among control and park villages/households included in the extensive survey (see text for details), and significance levels for the comparison of both groups (Mann-Whitney $U$ tests).

\begin{tabular}{|c|c|c|}
\hline Measure & Control & Park \\
\hline $\begin{array}{l}\text { Distance to nearest } \\
\text { park }(\mathrm{km})^{* * *}\end{array}$ & $65.7 \pm 5.7(45)$ & $14.7 \pm 0.8(72)$ \\
\hline Distance to market (hours) & $1.5 \pm 0.1(45)$ & $2.1 \pm 0.2(72)$ \\
\hline $\begin{array}{l}\text { Distance to larger town } \\
\text { (hours) }\end{array}$ & $2.7 \pm 0.3(45)$ & $3.5 \pm 0.3(72)$ \\
\hline $\begin{array}{l}\text { Village health access } \\
\text { (hours)* }\end{array}$ & $0.7 \pm 0.1(45)$ & $0.5 \pm 0.1(72)$ \\
\hline Education, household head & $0.7 \pm 0.0(641)$ & $0.8 \pm 0.0(796)$ \\
\hline BMI (household mean) ${ }^{\star \star}$ & $20.2 \pm 0.1(915)$ & $20.5 \pm 0.1(1,113)$ \\
\hline $\begin{array}{l}\text { BMI (household } \\
\text { minimum)* }\end{array}$ & $16.9 \pm 0.1(915)$ & $17.0 \pm 0.1(1,113)$ \\
\hline $\begin{array}{l}\% \text { body fat (household } \\
\text { mean)* }\end{array}$ & $11.0 \pm 0.2(916)$ & $11.9 \pm 0.3(1,113)$ \\
\hline $\begin{array}{l}\text { Days sick (household } \\
\text { mean) }\end{array}$ & $1.8 \pm 0.1(897)$ & $1.6 \pm 0.0(1,096)$ \\
\hline Alcohol abuse & $0.1 \pm 0.0(920)$ & $0.2 \pm 0.0(1,115)$ \\
\hline Days without food ${ }^{* *}$ & $1.5 \pm 0.0(920)$ & $1.6 \pm 0.0(1,115)$ \\
\hline Community trust score ${ }^{\star *}$ & $1.6 \pm 0.0(920)$ & $1.4 \pm 0.0(1,115)$ \\
\hline
\end{tabular}

Park and control villages selected for the intensive survey differed significantly in the area covered by different vegetation types within a $5 \mathrm{~km}$ radius. The area covered by closed rainforest ( $>40 \%$ cover of main tree layer) and seasonally flooded forest was greater around park than control villages (closed rainforest: $69.1 \pm \mathrm{SE} 3.0 \%, \mathrm{n}=26$ vs $82.9 \pm \mathrm{SE} 1.9 \%, \mathrm{n}=30$ control and park villages, respectively, $Z=-3.6, \mathrm{P}<0.001$; seasonally flooded rainforest: $2.0 \pm$ SE $0.5 \%$ vs $6.9 \pm$ SE $0.9 \%, Z=-3.5, \mathrm{P}<0.001)$ and closed to open rainforest ( $>15 \%$ cover of main tree layer) and forest/crop land mosaics were more common around control villages (closed to open rainforest: $16.8 \pm$ SE $1.6 \%$ vs 7.1 \pm SE $0.8 \%, Z=-4.3, \mathrm{P}<0.001$; forest/crop land mosaic: $9.9 \pm$ SE 1.4 vs $2.8 \pm$ SE $0.9 \%, Z=-3.7, \mathrm{P}<0.001)$.

\section{Household indicators}

Park households earned significantly less income than control households (PPP\$ 150.3 \pm SE 9.5 vs $220.9 \pm$ SE 14.9 for park and control households, respectively; $Z=-6.23$, $\mathrm{P}<0.001, \mathrm{n}=1,137$ ). Different directions of effects, however, were observed with specific income sources (Table 3 ). Control households sold significantly more mineral and cultivated goods than park households but there was no difference in income from sale of wild animal and plant products. Nevertheless, park households earned a greater proportion of sales income from wild products than control households $(25.3 \pm$ SE $1.5 \%$ vs $17.4 \pm$ SE $1.3 \%$ of all income, $Z=-2.9, \mathrm{P}=0.003, \mathrm{n}=657$ vs 597 park and control households, respectively). 
TABLE 3 Mean \pm SE total monthly income (purchasing power parity USD; see text for details) from various sources in control and park households and significance levels for the comparison of both groups (Mann-Whitney $U$ tests).

\begin{tabular}{|c|c|c|}
\hline Source of income & Control & Park \\
\hline Sale of forest goods & $32.0 \pm 4.4$ & $34.4 \pm 5.6$ \\
\hline Sale of cultivated goods ${ }^{* * *}$ & $75.5 \pm 5.2$ & $46.0 \pm 4.8$ \\
\hline Sale of manufactured goods & $20.2 \pm 6.7$ & $13.2 \pm 2.3$ \\
\hline Sale of minerals ${ }^{\star * \star}$ & $12.9 \pm 5.4$ & $1.0 \pm 0.7$ \\
\hline Sale of services & $3.0 \pm 1.7$ & $0.7 \pm 0.5$ \\
\hline All sales ${ }^{\star * \star}$ & $143.7 \pm 11.8$ & $95.3 \pm 8.0$ \\
\hline Salaries from government ${ }^{*}$ & $17.1 \pm 3.6$ & $21.5 \pm 3.8$ \\
\hline Salaries from NGOs ${ }^{*}$ & 0.0 & $1.6 \pm 0.6$ \\
\hline All salaries ${ }^{\star}$ & $29.0 \pm 4.6$ & $29.7 \pm 4.0$ \\
\hline Pensions & $36.0 \pm 7.5$ & $17.5 \pm 2.5$ \\
\hline Donations $^{* * *}$ & $12.2 \pm 1.6$ & $7.8 \pm 1.2$ \\
\hline
\end{tabular}

${ }^{\star} \mathrm{P}<0.05 ;{ }^{* * * \mathrm{P}<0.001}$

Total income from employment was greater in control than park households, mostly because of a difference in salary from private entities. Park households received significantly more income from the state and NGOs than control households but comparatively fewer donations. Although there was a significant difference in household size between park and control when expressed as AME (park: 5.0 \pm SE 0.2, $\mathrm{n}=913$; control: $5.7 \pm \mathrm{SE} 0.2, \mathrm{n}=705$; $Z=-4.3, \mathrm{P}<0.001$ ), expressing income per AME did not change the income differences from sales. However, salaries per AME did not differ between park and control households, regardless of the source. Wealth, as estimated by valuing a standard basket of assets for each household, did not differ between park and control households (park: PPP\$ 1,323.6 \pm SE 68.8, $\mathrm{n}=887$ vs control: PPP\$ $1,168.6 \pm$ SE 44.5, $\mathrm{n}=693 ; Z=-0.51, \mathrm{P}=0.612$ ).

Level of education of the household head did not differ between park and control households (Table 2; $Z=0.7, \mathrm{P}=$ 0.49 ). Overall, $47.2 \%$ of household heads had no education, $34 \%$ completed school to fifth grade (10-11 years), $15.9 \%$ up to ninth grade (14-15 years), and only $3 \%$ had higher levels of education (median: fifth grade).

\section{Health indicators}

The median BMI of park household members was slightly greater than that for control households, regardless of whether we used the household means or minima in the analysis (Table 2). The difference was small, however (household means: median $=20$, range $13.7-48.3$ vs 20.3, range 7.1-40.1, for control and park households, respectively; $Z=2.8, \mathrm{P}=0.005$; see Table 2 for sample sizes). Members of park households had a slightly greater percentage body fat than those of control households (Table 2; $Z=2.1, \mathrm{P}=0.033$ ) and the heads of control households reported slightly fewer days per month without consuming any food compared to park households $(Z=3.2, \mathrm{P}=0.001)$.

Members of control households reported more sick days in the previous month than park households (Table 2; $Z=-4.0, \mathrm{P}<0.001)$. For all of the most common illnesses examined, members of control households reported slightly more cases over the previous month than members of park households (fever: $0.74 \pm$ SE 0.02 vs $0.66 \pm$ SE 0.01 times; $Z=-4.5, \mathrm{P}<0.001$; diarrhoea: $0.36 \pm \mathrm{SE} 0.01$ vs $0.26 \pm \mathrm{SE}$ o.o times; $Z=-6.6, \mathrm{P}<0.001$; common cold: $0.64 \pm \mathrm{SE} 0.01$ vs $0.57 \pm$ SE 0.01 times; $Z=-4.1, \mathrm{P}<0.001 ; \mathrm{n}=3,959$ vs 4,916 members of control and park households, respectively). The median number of times with illnesses per month was zero for both park and control households.

\section{Consumption}

Among the main protein sources game meat was most commonly consumed. Mean household consumption was $9.4 \pm$ SE $0.7 \mathrm{~kg}$ of game meat per month per AME, with no difference between park and control households $(Z=-1.0$, $\mathrm{P}=0.92, \mathrm{n}=381$ vs 376 control and park households, respectively). Wild caught fish and domestic chicken and livestock were consumed more in park than control households but the difference was only significant for chicken consumption (fish: $1.1 \pm$ SE 0.1 vs $1.4 \pm$ SE $0.1 \mathrm{~kg}^{\text {month }}{ }^{-1}$ $\mathrm{AME}^{-1}$ for control and park households, respectively, $Z=-0.2, \mathrm{P}=0.84$; chicken: $0.2 \pm \mathrm{SE} 0.0$ vs $0.5 \pm \mathrm{SE} 0.1 \mathrm{~kg}$ month $^{-1} \mathrm{AME}^{-1}, Z=-5.0, \mathrm{P}<0.001$; livestock: $0.07 \pm \mathrm{SE}$ 0.01 vs $0.12 \pm \mathrm{SE} 0.03 \mathrm{~kg} \mathrm{month}^{-1} \mathrm{AME}^{-1}, Z=-0.8, \mathrm{P}=0.4$ ).

Consumption of vegetables and fruits, regardless of source, did not differ significantly between park and control households. Village medians for consumption of fruits and vegetables purchased from stores were higher in park than control villages (PPP\$ 2.7 vs 1.4 month $^{-1} \mathrm{AME}^{-1}, Z=-2.9$, $\mathrm{P}=0.003)$, as were the village medians for meat purchased from stores (PPP\$ 2.7 vs 1.8 month $^{-1} \mathrm{AME}^{-1}, \mathrm{n}=498$ and 485 for park and control households, respectively, $Z=-4.0$, $\mathrm{P}<0.001)$. There were no differences between park and control households in the consumption of non-food items.

\section{Do livelihood measures vary with distance to park?}

Results of the generalized linear models controlling for distance to the nearest park boundary are provided in Table 4. The majority of livelihood measures differed between sites, and interactions between site and distance to parks were common. Only consumption of animal protein (in $\mathrm{kg}$ ) and vegetables/fruits purchased from stores (in XAF) showed a consistent and significant decline with greater distance from park boundaries. This result indicates that variation in most livelihood measures was more influenced by site-specific idiosyncrasies than a consistent effect of distance to parks. 
TABLE 4 Results of generalized linear models investigating the effects of park and distance to nearest park boundary on variation in livelihood measures across villages. Site evaluates differences between parks, Distance evaluates the effect of distance to park boundaries, and Site ${ }^{\star}$ Distance evaluates the interaction between Site and Distance. Park identifies parks with significant distance effects, and Coefficient gives the effect sizes and directions.

\begin{tabular}{|c|c|c|c|c|c|}
\hline Measure $^{1}$ & Site $^{2}$ & Distance $^{2}$ & Site $^{\star}$ Distance ${ }^{2}$ & Park $^{3}$ & Coefficient \\
\hline Wealth (XAF $\mathrm{AME}^{-1}$ ) & $55.79^{\star \star *}$ & 3.55 & $12.30^{\star \star}$ & IVD & $-0.017^{\star \star}$ \\
\hline Sale of forest goods & $26.65^{* * *}$ & 2.23 & $10.66^{*}$ & BIR & $0.04^{\star *}$ \\
\hline \multirow[t]{3}{*}{ Sale of forest goods (\% of all income) } & $19.58^{\star * *}$ & 0.23 & $37.62^{* * *}$ & IVD & $0.018^{* * *}$ \\
\hline & & & & MDC & $-0.014^{\star *}$ \\
\hline & & & & WKA & $-0.025^{\star}$ \\
\hline Sale of cultivated goods & $28.09^{\star * *}$ & 1.23 & 3.57 & MDC & $0.005^{\star * *}$ \\
\hline Sale of manufactured goods & 1.61 & 2.60 & 0.28 & & \\
\hline Sale of minerals & $10.70^{* *}$ & $33.05^{\star * *}$ & $157.01^{\star * *}$ & IVD & $-0.025^{\star *}$ \\
\hline \multirow[t]{2}{*}{ Sale of services } & $5.96^{*}$ & 0.09 & $19.19^{* * *}$ & IVD & $-0.013^{\star * *}$ \\
\hline & & & & MDC & $0.012^{\star}$ \\
\hline All sales & $11.72^{\star \star}$ & 0.02 & 2.13 & IVD & $0.008^{\star}$ \\
\hline Salary from private companies & $20.29^{* * *}$ & $4.60^{*}$ & $7.75^{\star}$ & & \\
\hline All salaries & 4.11 & 1.16 & 6.29 & IVD & $-0.021^{\star}$ \\
\hline All income & $41.96^{* * *}$ & 0.13 & $9.35^{\star}$ & WKA & $0.009^{* * *}$ \\
\hline \multirow[t]{2}{*}{ Household size (AME) } & $141^{\star * *}$ & 2.21 & 3.84 & IVD & $0.004^{*}$ \\
\hline & & & & MDC & $0.001^{*}$ \\
\hline \multirow[t]{2}{*}{ Education, household head } & $27.95^{\star * *}$ & 0.07 & 9.59 & MDC & $-0.002^{*}$ \\
\hline & & & & WKA & $0.009^{*}$ \\
\hline BMI (household mean) & $21.81^{\star * *}$ & $10^{* *}$ & $33.53^{\star * *}$ & IVD & $-0.002^{* * *}$ \\
\hline \multirow{2}{*}{$\%$ body fat } & $118.19^{* * *}$ & 0.01 & $18.69^{* * *}$ & IVD & $-0.005^{\star *}$ \\
\hline & & & & WKA & $0.004^{* *}$ \\
\hline \multirow[t]{2}{*}{ Days sick (household mean) } & $37.95^{\star * *}$ & 0.16 & $20.55^{\star * *}$ & MDC & $0.003^{* * *}$ \\
\hline & & & & WKA & $-0.006^{* *}$ \\
\hline \multirow[t]{3}{*}{ Days without food (household head) } & $34^{* * *}$ & $13.25^{\star * *}$ & $29.65^{\star * *}$ & BIR & $-0.014^{* * *}$ \\
\hline & & & & IVD & $0.002^{\star}$ \\
\hline & & & & $\mathrm{MDC}$ & $-0.001^{\star}$ \\
\hline \multirow[t]{2}{*}{ Community trust score } & $50.02^{\star \star \star}$ & $9.13^{\star *}$ & $56.7^{\star \star \star}$ & BIR & $-0.022^{\star * *}$ \\
\hline & & & & IVD & $0.008^{* * *}$ \\
\hline \multirow[t]{4}{*}{ Distance to larger town (hours) } & $1,132.5^{\star * *}$ & $27.06^{* * *}$ & $1,192.03^{* * *}$ & BIR & $0.014^{\star * \star}$ \\
\hline & & & & IVD & $0.018^{* * *}$ \\
\hline & & & & MDC & $-0.008^{* * *}$ \\
\hline & & & & WKA & $-0.015^{* * *}$ \\
\hline \multirow[t]{4}{*}{ Distance to market (hours) } & $895.7^{\star * *}$ & $79.32^{\star * *}$ & $842.55^{\star * *}$ & BIR & $-0.076^{* * *}$ \\
\hline & & & & IVD & $0.017^{\star * *}$ \\
\hline & & & & $\mathrm{MDC}$ & $-0.005^{\star * *}$ \\
\hline & & & & WKA & $-0.022^{* * *}$ \\
\hline \multirow[t]{2}{*}{ Village health access (hours) } & $113.36^{* * *}$ & 1.85 & $99.58^{\star * *}$ & MDC & $0.005^{\star * *}$ \\
\hline & & & & WKA & $-0.011^{* * *}$ \\
\hline Consumption of bushmeat & 0.03 & 0.10 & 0.35 & & \\
\hline Consumption of chicken & 6.58 & 2.08 & 5.17 & IVD & $-0.037^{\star}$ \\
\hline Consumption of livestock & 3.65 & 0.87 & 0.03 & & \\
\hline Consumption of fish & $40.89^{\star * *}$ & 1.15 & $24.76^{\star * *}$ & BIR & $0.036^{* * *}$ \\
\hline \multirow[t]{2}{*}{ Consumption of meat from stores } & $7.37^{\star}$ & $5.75^{\star}$ & $7.91^{\star}$ & IVD & $-0.023^{* * *}$ \\
\hline & & & & $\mathrm{MDC}$ & $-0.006^{* * *}$ \\
\hline \multirow[t]{2}{*}{ Consumption of vegetables/fruits } & $12.40^{* *}$ & 2.2 & $10.76^{\star *}$ & BIR & $0.017^{\star}$ \\
\hline & & & & IVD & $-0.006^{\star}$ \\
\hline \multirow{2}{*}{$\begin{array}{l}\text { Consumption of vegetables/fruits } \\
\text { from stores only }\end{array}$} & $26.04^{\star * *}$ & $16.46^{* * *}$ & $8.03^{*}$ & BIR & $-0.015^{\star *}$ \\
\hline & & & & IVD & $-0.018^{\star *}$ \\
\hline Value of non-food items bought & $6.91^{\star}$ & 1.21 & 4.62 & $\mathrm{MDC}$ & $-0.005^{\star *}$ \\
\hline
\end{tabular}

${ }^{*} \mathrm{P}<0.05,{ }^{* *} \mathrm{P}<0.01,{ }^{* * *} \mathrm{P}<0.001$

${ }^{1}$ Income from sales and salaries are XAF month ${ }^{-1} \mathrm{AME}^{-1}$, consumption measures are kg month ${ }^{-1} \mathrm{AME}^{-1}$ for bushmeat, chicken, livestock and fish, and XAF month ${ }^{-1} \mathrm{AME}^{-1}$ for all other consumption

${ }^{2}$ Values given are Wald $\chi^{2}$ statistic

${ }^{3}$ BIR, Biringou; IVD, Ivindo; MDC, Monts de Cristal; WKA, Waka 
What factors best distinguish between park and control households?

In our multivariate logistic models distance to park boundary was the single best predictor for classifying households into park and control (94.5\% of all households classified correctly by the model). However, as this solution was trivial we removed that predictor to examine effects of other factors of interest. The best model, with a predictive power of $59.4 \%$ (44.7\% for control households, $69.6 \%$ of park households), included household size (odds ratio $=$ 0.96) and consumption of chicken (odds ratio $=1.37$ ). Thus, household sizes were smaller in park than control villages, and households in park villages consumed greater quantities of chicken. The low predictive power of the model suggests, however, that none of the livelihood measures differed greatly and consistently between park and control households. To reduce random variability among households and improve model fits, we used village means in a separate binary logistic regression. Results were identical to the household level analysis, with household size (odds ratio $=0.76$ ) and consumption of chicken (odds ratio $=13.85$ ) being the most useful factors distinguishing between park and control ( 73.1 and $70 \%$ of villages, respectively, classified correctly).

\section{Discussion}

Our goal was to assess whether communities with traditional and ongoing claims to resources within the boundaries of national parks differed in livelihood measures from control communities that do not use or claim access to these same resources. Our results show that there were differences between these communities in land cover and in income generating activities. Park households relied to a greater extent on wild animal and plant products, and control households obtained relatively more income from agriculture. However, although park households had significantly lower overall income than control households from the sale of goods, indicators of welfare such as consumption, access to health care, education and wealth did not differ significantly between the two groups. In particular, households in park and control villages received their main animal protein from wildlife, similar to what has been reported for other parts of Gabon (Wilkie \& Carpenter, 1999; van Vliet \& Nasi, 2008; Blaney et al., 2009) and elsewhere (Lahm, 1993). Given the greater proportion of land covered with intact forest around park villages, the greater reliance on forest resources among park households was not unexpected. This suggests that livelihoods of communities with traditional claims to park resources may be more likely to suffer if conservation and management practices restrict access to, and use of, forest products (McElwee, 2010) and do not provide alternative income sources and protein supplies (Loibooki et al., 2002; Robinson \& Bennett, 2004; Ohl-Schacherer et al., 2007).

There appeared to be a small but significant difference in welfare measures related to food stability and incidence of diseases. Heads of households in park villages did not consume food on twice as many days as heads of households in control villages. As control households rely more on cultivated foods they may experience less volatility in food supply than park households that rely more on wild food resources (van Vliet \& Nasi, 2008). The difference between park and control households was small, however, and its relevance as an indicator of nutritional status or welfare is uncertain. The finding that control households were more likely to suffer from common infectious illnesses could be related to the larger size of control villages, because larger aggregations of hosts may better sustain populations of disease vectors (Anderson \& May, 1979; Lindenfors et al., 2007).

In general, previous empirical assessments of the relationship between human welfare and protected areas have found evidence for both positive and negative associations, supporting the notion that any effects tend to be highly localized and specific to each protected area. Furthermore, we still know little about the long-term effects of protected areas on human welfare because longitudinal data on welfare indicators are generally not available for many developing nations, particularly in Africa. Analysis of the long-term influences of protected areas on human welfare using historical and current indicators of welfare in Costa Rica and Thailand (Andam et al., 2010), two relatively welldeveloped countries compared to Sub-Saharan Africa, indicated that protected areas improved human livelihoods after confounding variables were controlled for, although imperfect measures, great variability, and the unplanned nature of the study left some uncertainty about true cause and effect relationships.

Although our comparison of park and control households revealed no overall systematic difference in welfare measures despite variation in land use and income, sitespecific conditions lead to significant variation across the study sites for almost all our livelihood measures. For example, income differences between park and control communities were most apparent at Waka National Park but not significantly different at other sites (Fig. 2). Similarly, consumption of vegetables and fruits was significantly lower in park than control villages at Biringou, higher in park than control villages at Ivindo, and not significantly different at Monts de Cristal (Fig. 3). Such siteto-site variation in livelihood measures probably results from existing variation in environmental, historical, social and economic factors (Fa et al., 2002, 2009). Understanding the drivers of these differences has implications for management and poverty intervention schemes, as well as the future assessments of livelihood impacts of establishing and 


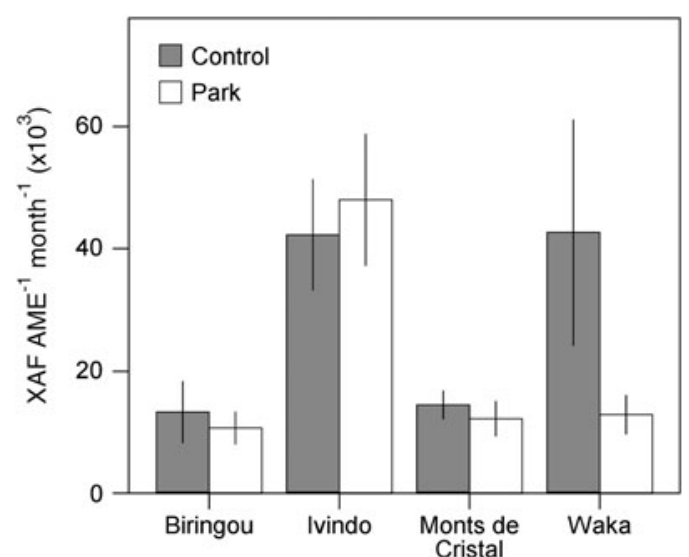

FIG. 2 Site-specific variation in household income from all sources (mean $\pm 95 \%$ confidence interval) for households in control and park villages at the four National Park study sites (Fig. 1).

managing protected areas. This site-specific variation in the difference between park and control households also lends further support to the idea that proximity to park resources itself was not the primary cause of the variation we observed but that these differences are caused by local idiosyncrasies at each site, which remain to be explored.

As this study evaluated variation in livelihood measures before the implementation of laws governing the newly established parks, we cannot make inferences about the role of these parks in influencing human welfare. We can, however, assess the influence of being close to the natural resources that are protected in these parks, and found that the variation in resource access between control and park villages was not sufficient to cause major differences in human livelihood measures. A future survey (Wilkie et al., 2006), to be conducted within the next 5-10 years, will allow conclusions to be drawn about the direct influence of park management practices on human welfare and contribute to

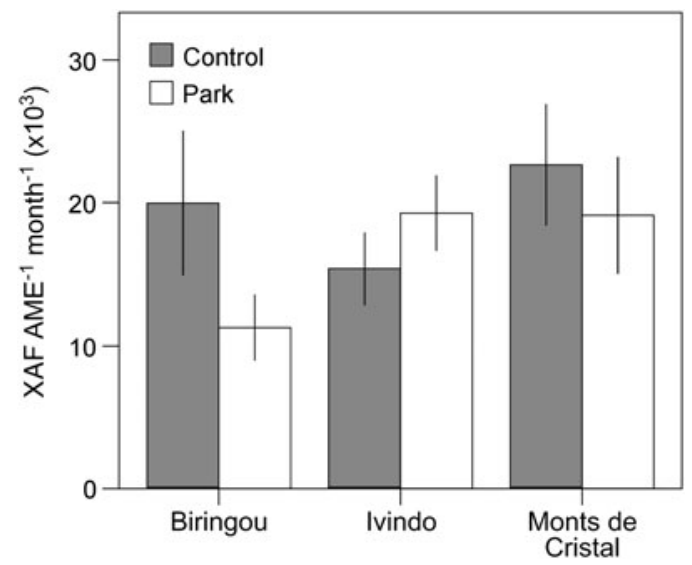

FIG. 3 Site-specific variation in consumption of fruits and vegetables (mean $\pm 95 \% \mathrm{CI}$ ) for households in control and park villages at three of the four National Park study sites (Fig. 1). the ongoing debate on livelihood impacts of establishing protected areas as a means for sustainable biodiversity conservation.

\section{Acknowledgements}

The Parks and People research in Gabon is supported with start-up funding from the John D. and Catherine T. MacArthur Foundation, and is being undertaken by Boston College in collaboration with the Conseil National des Parcs Nationaux of Gabon and the Wildlife Conservation Society. We acknowledge the work of our team of Gabonese social scientists: Estelle Bouanga, Guy-Modeste Mengue, Franck Mouleka and Yves-Eric Pangou.

\section{References}

Andam, K.S., Ferraro, P.J., Sims, K.R.E., Healy, A. \& Holland, M.B. (2010) Protected areas reduced poverty in Costa Rica and Thailand. Proceedings of the National Academy of Sciences of the USA, 107, 9996-10001.

Anderson, R.M. \& MAY, R.M. (1979) Population biology of infectious diseases: part 1. Nature, 280, 361-367.

Blaney, S., Beaudry, M. \& Latham, M. (2009) Contribution of natural resources to nutritional status in a protected area of Gabon. Food and Nutrition Bulletin, 30, 49-62.

Brockington, D., Igoe, J. \& Schmidt-Soltau, K. (2006) Conservation, human rights, and poverty reduction. Conservation Biology, 20, 250-252.

Cernea, M.M. \& Schmidt-Soltau, K. (2006) Poverty risks and national parks: policy issues in conservation and resettlement. World Development, 34, 1808-1830.

Crookes, D., Humphreys, D., Masroh, F., Tarchie, B. \& Milner-Gulland, E.J. (2007) The role of hunting in village livelihoods in the Ashanti region, Ghana. South African Journal of Economic and Management Sciences, 10, 457-469.

Deaton, A. (1997) The Analysis of Household Surveys: A Microeconometric Approach to Development Policy. Johns Hopkins University Press, Baltimore, USA.

Demmer, J. \& Overman, H. (2001) Indigenous People Conserving the Rain Forest? The Effect of Wealth and Markets on the Economic Behaviour of Tawahka Amerindians in Honduras. Tropenbos International, Wageningen, The Netherlands.

De Sherbinin, A. (2008) Is poverty more acute near parks? An assessment of infant mortality rates around protected areas in developing countries. Oryx, 42, 26-35.

Dudley, N., Mansourian, S., Stolton, S. \& Suksuwan, S. (2008) Safety Net: Protected Areas and Poverty Reduction. WWF, Gland, Switzerland.

ESA (European Space Agency) (2008) Regional Africa GlobCover Land Cover. Version 2.2. European Space Agency GlobCover Project, led by MEDIAS-France. Http://ionia1.esrin.esa.int [accessed 10 April 2011].

Fa, J.E., Albrechtsen, L., Johnson, P.J. \& Macdonald, D.W. (2009) Linkages between household wealth, bushmeat and other animal protein consumption are not invariant: evidence from Rio Muni, Equatorial Guinea. Animal Conservation, 12, 599-610.

Fa, J.E., Juste, J., Burn, R.W. \& Broad, G. (2002) Bushmeat consumption and preferences of two ethnic groups in Bioko Island, West Africa. Human Ecology, 30, 397-416. 
FAO (Food and Agriculture Organization of the United Nations) (2005) Land Cover Classification System. Classification Concepts and User Manual. Software Version 2. Food and Agriculture Organization of the United Nations, Rome, Italy.

FERRARo, P.J. (2002) The local costs of establishing protected areas in low-income nations: Ranomafana National Park, Madagascar. Ecological Economics, 43, 261-275.

Ghimire, K.B. \& Pimbert, M.P. (eds) (1997) Social Change and Conservation: Environmental Politics and Impacts of National Parks and Protected Areas. Earthscan, London, UK.

Hegde, R. \& Enters, T. (2000) Forest products and household economy: a case study from Mudumalai Wildlife Sanctuary, Southern India. Environmental Conservation, 27, 250-259.

James, W.P.T. \& Schofield, E.C. (1990) Human Energy Requirements. A Manual for Planners and Nutritionists. Oxford University Press, Oxford, UK.

LAHM, S.A. (1993) Utilization of forest resources and local variation of wildlife populations in northeastern Gabon. In Tropical Forests, People and Food: Biocultural Interactions and Applications to Development (eds C.M. Hladik, A. Hladik, O.F. Linares, H. Pagezy, A. Semple \& M. Hadley), pp. 213-226. UNESCO, Paris, France.

Lindenfors, P., Nunn, C.L., Jones, K.E., Cunningham, A.A., Sechrest, W. \& Gittleman, J.L. (2007) Parasite species richness in carnivores: effects of host body mass, latitude, geographical range and population density. Global Ecology and Biogeography, 16, 496-509.

Ling, S. \& Milner-Gulland, E.J. (2006) Assessment of the sustainability of bushmeat hunting based on dynamic bioeconomic models. Conservation Biology, 20, 1294-1299.

Loibooki, M., Hofer, H., Campbell, K.L.I. \& East, M.L. (2002) Bushmeat hunting by communities adjacent to the Serengeti National Park, Tanzania: the importance of livestock ownership and alternative sources of protein and income. Environmental Conservation, 29, 391-398.

McElwee, P.D. (2010) Resource use among rural agricultural households near protected areas in Vietnam: the social costs of conservation and implications for enforcement. Environmental Management, 45, 113-131.

Mullan, K., Kontoleon, A., Swanson, T.M. \& Zhang, S.Q. (2010) Evaluation of the impact of the natural forest protection program on rural household livelihoods. Environmental Management, 45, 513-525.

Naughton-Treves, L., Holland, M.B. \& Brandon, K. (2005) The role of protected areas in conserving biodiversity and sustaining local livelihoods. Annual Review of Environment and Resources, 30, 219-252.

Nyahongo, J.W., Holmern, T., Kaltenborn, B.P. \& Roskaft, E. (2009) Spatial and temporal variation in meat and fish consumption among people in the western Serengeti, Tanzania: the importance of migratory herbivores. Oryx, 43, 258-266.

Ohl-Schacherer, J., Shepard, G.H., Kaplan, H., Peres, C.A., LEVI, T. \& YU, D.W. (2007) The sustainability of subsistence hunting by Matsigenka native communities in Manu National Park, Peru. Conservation Biology, 21, 1174-1185.

Robinson, J.G. \& Bennett, E.L. (2004) Having your wildlife and eating it too: an analysis of hunting sustainability across tropical ecosystems. Animal Conservation, 7, 397-408.

Roe, D. (2008) The origins and evolution of the conservationpoverty debate: a review of key literature, events and policy processes. Oryx, 42, 491-503.

Rowcliffe, J.M., De Merode, E. \& Cowlishaw, G. (2004) Do wildlife laws work? Species protection and the application of a prey choice model to poaching decisions. Proceedings of the Royal Society of London, Series B. Biological Sciences, 271, 2631-2636.

Sanderson, S.E. \& Redford, K.H. (2003) Contested relationships between biodiversity conservation and poverty alleviation. Oryx, $37,389-390$

Scherl, L.M., Wilson, A., Wild, R., Blockhus, J., Franks, P., McNeely, J.A. \& McShane, T.O. (2004) Can Protected Areas Contribute to Poverty Reduction? Opportunities and Limitations. IUCN, Gland, Switzerland.

Stolton, S. \& Dudley, N. (2010) Vital Sites: The Contribution of Protected Areas to Human Health. WWF and Equilibrium, Gland, Switzerland.

TAYLOR, R. (2009) Community based natural resource management in Zimbabwe: the experience of CAMPFIRE. Biodiversity and Conservation, 18, 2563-2583.

The National Commission for the Protection of Human Subjects of Biomedical and Behavioral Research (1979) The Belmont Report. Ethical Principles and Guidelines for the Protection of Human Subjects of Research. Department of Health, Education, and Welfare, Publication No. (OS) 78-0013 \& (OS) 78-0014, Washington, DC, USA.

Upton, C., Ladle, R., Hulme, D., Jiang, T., Brockington, D. \& Adams, W.M. (2008) Are poverty and protected area establishment linked at a national scale? Oryx, 42, 19-25.

van Vliet, N. \& Nasi, R. (2008) Hunting for livelihood in northeast Gabon: patterns, evolution, and sustainability. Ecology and Society, 13, article number 33 .

Wells, M. \& McShane, T.O. (2004) Integrating protected area management with local needs and aspirations. Ambio, 33, 513-519.

West, P., Igoe, J. \& Brockington, D. (2006) Parks and peoples: the social impact of protected areas. Annual Review of Anthropology, 35, 251-277.

Wilkie, D.S. \& CARPenter, J.F. (1999) Bushmeat hunting in the Congo Basin: an assessment of impacts and options for mitigation. Biodiversity and Conservation, 8, 927-955.

Wilkie, D.S., Morelli, G.A., Demmer, J., Starkey, M., Telfer, P. \& STeIL, M. (2006) Parks and people: assessing the human welfare effects of establishing protected areas for biodiversity conservation. Conservation Biology, 20, 247-249.

Wilkie, D.S., Starkey, M., Abernethy, K., Effa, E.N., Telfer, P. \& Godoy, R. (2005) Role of prices and wealth in consumer demand for bushmeat in Gabon, central Africa. Conservation Biology, 19, 268-274.

World BANK (2008) World Development Indicators. The World Bank, Washington, DC, USA.

\section{Biographical sketches}

STEFFen Foerster is a behavioural ecologist with research interests in wildlife conservation and management. D A VID W ILKIE is an ecologist and Gilda Morelli is a cultural and developmental psychologist; both have worked with hunter-gatherers for over 20 years and are interested in the economic and social factors that drive natural resource use. JoSEFIEN DEMMER is an ecologist interested in human ecology. MALCOLM STARKEY is a geographer, PAUL TELFER is a primatologist and MATTHEW STEIL is a conservation biologist; all continue to work in Central Africa helping government agencies, private sector companies and local communities manage natural resources sustainably and conserve the region's spectacular wildlife. 